\title{
Stem cell therapy for retinal diseases: update
}

Rubens Camargo Siqueira*1-3

\begin{abstract}
Distinct stem cell types have been established from embryos and identified in the fetal tissues and umbilical cord blood as well as in specific niches in many adult mammalian tissues and organs such as bone marrow, brain, skin, eyes, heart, kidneys, lungs, gastrointestinal tract, pancreas, liver, breast, ovaries, and prostate. All stem cells are undifferentiated cells that exhibit unlimited self-renewal and can generate multiple cell lineages or more restricted progenitor populations that can contribute to tissue homeostasis by replenishing the cells or to tissue regeneration after injury. The remarkable progress of regenerative medicine in the last few years indicates promise for the use of stem cells in the treatment of ophthalmic disorders. Experimental and human studies with intravitreal bone marrow-derived stem cells have begun. This paper reviews recent advances and potential sources of stem cells for cell therapy in retinal diseases.
\end{abstract}

\section{Introduction \\ Stem cells}

Stem cell (SC) therapy is not a new concept. In the aftermath of the bombings of Hiroshima and Nagasaki in 1945, researchers discovered that bone marrow (BM) transplanted into irradiated mice produced hematopoiesis [1]. Hematopoietic stem cells (HSCs) were first identified in 1961, and their ability to migrate and differentiate into multiple cell types was documented [2].

Distinct SC types have been established from embryos and identified in fetal tissues and umbilical cord blood (UCB) as well as in specific niches in many adult mammalian tissues and organs such as BM, brain, skin, eyes, heart, kidneys, lungs, gastrointestinal tract, pancreas, liver, breast, ovaries, prostate, and testis [3]. All SCs are

*Correspondence: rubenssiqueira@terra.com.br

${ }^{2}$ Rubens Siqueira Research Center, São José do Rio Preto, Rua Saldanha Marinho

2815 conj 42, São Paulo 15010-100, Brazil

Full list of author information is available at the end of the article undifferentiated cells that exhibit unlimited self-renewal and can generate multiple cell lineages or more restricted progenitor populations that can contribute to tissue homeostasis by replenishing the cells or to tissue regeneration after injury $[4,5]$.

A progenitor cell is a biological cell that, like an SC, has a tendency to differentiate into a specific type of cell but is already more specific than an SC and is pushed to differentiate into its 'target' cell. The most important difference between SCs and progenitor cells is that SCs can replicate indefinitely, whereas progenitor cells can divide only a limited number of times. Controversy about the exact definition remains and the concept is still evolving.

Several investigations [5-7] have been carried out with isolated embryonic, fetal, and adult SCs in a well-defined culture microenvironment to define the sequential steps and intracellular pathways that are involved in their differentiation into the specific cell lineages. More particularly, different methods, including the use of cell feeder layers, cell-free conditions, and extracellular matrix molecules such as collagen, gelatin, and laminin and diverse growth factors and cytokines, have been developed for the in vitro culture of SCs $[3,5]$.

\section{Retinal diseases}

Age-related macular degeneration (AMD), glaucoma, and diabetic retinopathy are the three most common causes of visual impairment and legal blindness in developed countries [8-10]. One common denominator of these conditions is progressive loss of the neural cells of the eye - photoreceptors, interneurons, and retinal ganglion cells, or RGCs - and essential supporting cells such as the retinal pigment epithelium (RPE). Retinal dystrophies - retinitis pigmentosa (RP) (Figure 1), Stargardt disease, Best disease, Leber congenital amaurosis, and so on - all evolve with early loss of photoreceptors and subsequent loss of RGC. Recent years have seen enormous progress in the treatment options that stop the progression of AMD from a neovascular state to fibrosis, that slow down the progression of glaucoma by reducing intraocular pressure, and that prevent progression of diabetic retinopathy by optimizing glycemic control and treat retinal neovascularization early [11-14]. However, irreversible visual loss still occurs in a significant 


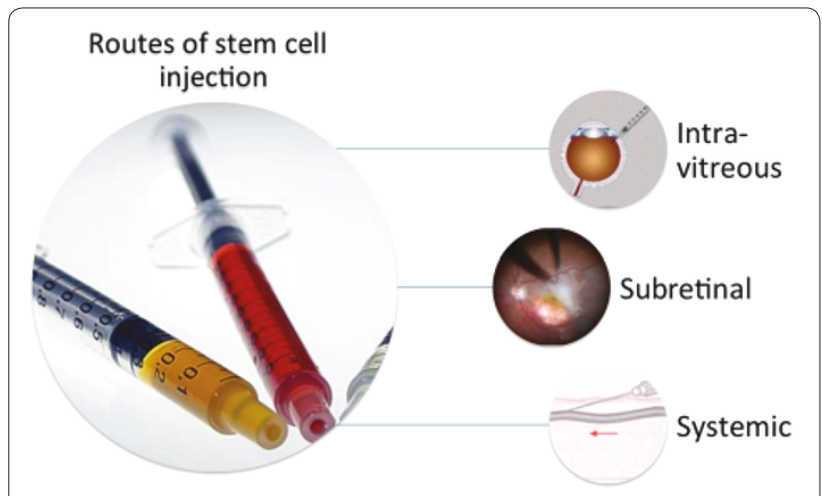

Figure 1. Routes of stem cell injection for retinal diseases.

proportion of cases. Research is aimed at developing novel treatments using neuroprotective and regenerative strategies.

SCs can potentially be used for both neuroprotection and cell replacement. Intravitreal delivery of neurotrophic factors slows down photoreceptor degeneration in rodent models of RP, RGC loss in glaucoma models, and optic nerve and optic tract trauma, but the effect may be temporary. Slow-release preparations and gene therapy approaches used to induce retinal cells to secrete neurotrophic factors are two ways to induce longer-term effects. A third option is to use SCs as long-term delivery agents, possibly encapsulated in a device, because many SCs either secrete neurotrophins naturally or can be genetically engineered to do so [15-17]. SCs can be injected into the eye through the intravitreal or subretinal technique [18-21].

Progress has also been made in the field of photoreceptor, RPE, and RGC replacement by $\mathrm{SCs}$ and progenitor cells, although long-term restoration of visual function has not been confirmed. The recent discoveries that human fibroblasts can be 'reprogrammed' to behave like embryonic SCs and that adult eyes harbor retinal progenitor cells (RPCs) also increase the potential availability of SCs for transplantation, including autologous transplantation, and stimulate intrinsic 'self-regeneration', which could potentially overcome a lot of the problems associated with non-autologous transplantation in humans [15].

\section{Potential sources of stem cells for cell therapy in retinal diseases \\ Bone marrow-derived stem cells}

BM-derived SCs have been proposed as a potential source of cells for regenerative medicine [9,22]. This is based on the assumption that HSCs isolated from BM are plastic and are able to 'transdifferentiate' into tissuecommitted SCs for other organs (for example, heart, liver, or brain). Unfortunately, the concept of SC plasticity was not confirmed in recent studies, and previously encouraging data demonstrating this phenomenon in vitro could be explained by a phenomenon of cell fusion or, as believed by our group, by the presence of heterogeneous populations of SCs in BM [23]. The identification of very small, embryonic-like SCs in BM supports the notion that this tissue contains a population of primitive SCs, which, if transplanted together with HSCs, would be able to regenerate damaged tissues in certain experimental settings. Cells from BM are easily and safely aspirated. After administration of local anesthesia, about $10 \mathrm{~mL}$ of the $\mathrm{BM}$ is aspirated from the iliac crest by means of a sterile BM aspiration needle; subsequently, mononuclear BM-derived SCs are separated by using the Ficoll density separation method $[3,18]$.

SC-based therapy has been tested in animal models for several diseases, including neurodegenerative disorders such as Parkinson disease, spinal cord injury, and multiple sclerosis. The replacement of lost neurons that are not physiologically replaced is pivotal for therapeutic success. In the eye, degeneration of neural cells in the retina is a hallmark of widespread ocular diseases such as AMD and RP. In these cases, the photoreceptor loss that occurs as a primary event (as in RP) or secondary to loss of RPE (as in AMD) leads to blindness [3,9].

$\mathrm{BM}$ is an ideal tissue for studying SCs because of its accessibility and because proliferative dose responses of BM-derived SCs can be readily investigated. Furthermore, there are a number of well-defined mouse models and cell surface markers that allow effective studies of hematopoiesis in healthy and injured mice. Because of these characteristics and the experience of BM transplantation in the treatment of hematological cancers, BM-derived SCs have also become an important tool in regenerative medicine. The $\mathrm{BM}$ harbors at least two distinct SC populations: HSCs and mesenchymal stem cells (MSCs) [24,25].

\section{Hematopoietic stem cells}

HSCs are multipotent SCs that give rise to all of the blood cell types, including myeloid lineages (monocytes, macrophages, neutrophils, basophils, eosinophils, erythrocytes, megakaryocytes/platelets, and dendritic cells) and lymphoid lineages ( $\mathrm{T}$ cells, B cells, and natural killer cells). HSCs are found in adult BM in, for example, femurs, hips, ribs, the sternum, and other bones. Cells can be obtained directly from the hip by using a needle and syringe (Figure 1) or from the blood after pretreatment with cytokines, such as G-CSFs (granulocyte colonystimulating factors), that induce cells to be released from the BM compartment. Other sources for clinical and scientific use include UCB and placenta [23,24].

In reference to phenotype, HSCs are identified by their small size, lack of lineage markers, low staining (side 
population) by vital dyes such as rhodamine 123 (rhodamine-dull, also called rholo) or Hoechst 33342, and presence of various surface antigenic markers, many of which belong to the cluster of differentiation (CD) series (CD34, CD38, CD90, CD133, CD105, and CD45) and also c-kit and SC factor receptor [26-31]. Otani and colleagues [16] demonstrated that, whenever a fraction of mouse or human adult BM-derived SCs (lineage-negative hematopoietic stem cells, or Lin-HSCs) containing endothelial precursors stabilizes and rescues retinal blood vessels that would ordinarily completely degenerate, a dramatic neurotrophic rescue effect is also observed. Retinal nuclear layers are preserved in two mouse models of retinal degeneration, $r d 1$ and $r d 10$, and detectable, albeit severely abnormal, electroretinogram recordings are observed in rescued mice at times when they are never observed in control-treated or untreated eyes. The normal mouse retina consists predominantly of rods, but the rescued cells after treatment with Lin-HSCs are nearly all cones. Microarray analysis of rescued retinas demonstrates significant upregulation of many antiapoptotic genes, including small heat shock proteins and transcription factors.

Some reports have demonstrated the clinical feasibility of the intravitreal administration of autologous bone marrow-derived mononuclear cells (ABMCs) in patients with advanced degenerative retinopathies [32,33]. More recently, our group conducted a prospective, phase I, non-randomized, open-label study that included three patients with RP and two patients with cone-rod dystrophy and an Early Treatment Diabetic Retinopathy Study best-corrected visual acuity of 20/200 or worse [34]. Evaluations such as best-corrected visual acuity, fullfield electroretinography, kinetic visual field (Goldman), fluorescein and indocyanine green angiography, and optical coherence tomography were performed at baseline and $1,7,13,18,22$, and 40 weeks after intravitreal injection of $10 \times 10^{6} \mathrm{ABMCs}(0.1 \mathrm{~mL})$ into one study eye of each patient. No adverse event associated with the injection was observed. A 1-line improvement in bestcorrected visual acuity was measured in four patients 1 week after injection and was maintained throughout follow-up. Three patients showed undetectable electroretinography responses at all study visits, whereas one patient demonstrated residual responses for darkadapted standard flash stimulus (a wave amplitude of approximately $35 \mathrm{mV}$ ), which remained recordable throughout follow-up, and one patient showed a small response (a wave amplitude of approximately $20 \mathrm{mV}$ ) recordable only at weeks $7,13,22$, and 40 . Visual fields showed no reduction (with a Goldman Standard V5e stimulus) for any patient at any visit. No other changes were observed on optical coherence tomography or fluorescein and indocyanine green angiograms. We conclude that intravitreal injection of ABMCs in eyes with advanced RP or cone-rod dystrophy was associated with no detectable structural or functional toxicity over a period of 10 months [34].

\section{Mesenchymal stem cells}

MSCs are progenitors of all connective tissue cells. In adults of multiple vertebrate species, MSCs have been isolated from BM and other tissues, expanded in culture, and differentiated into several tissue-forming cells such as bone, cartilage, fat, muscle, tendon, liver, kidney, heart, and even brain cells.

According to the International Society for Cellular Therapy [35], there are three minimum requirements for a population of cells to be classified as MSCs. The first is that MSCs, unlike BM-derived hematopoietic cells, are isolated from a population of mononuclear cells on the basis of their selective adherence to the surface of the plastic of culture dishes; a disadvantage of this method of identification is the possible contamination by hematopoietic cells and cellular heterogeneity with respect to the potential for differentiation. Second, CD105, CD73, and CD90 must be present and CD34, CD45, CD14 or CD11b, CD79, or CD19 and HLA-DR must not be expressed in more than $95 \%$ of the cells in culture. Finally, the cells can be differentiated into bone, fat, and cartilage [36].

A number of studies have shown that BM-derived MSCs can differentiate into cells expressing photoreceptor proteins when injected into the subretinal space $[37,38]$. Interestingly, it has been suggested that rat MSCs can be made to express photopigment (rhodopsin) in vitro simply by adding epidermal growth factor to the culture media [39]. Additionally, although other retinarelevant cell types have been engineered, a number of studies have shown that BM- or adipose tissue-derived MSCs are converted to RPE cells [39-41]. As with work on other neuronal phenotypes, however, there has now been a reassessment of the ability of MSCs to differentiate into functionally useful retinal cells. Some studies have shown that transplanted BM-derived MSCs do not differentiate into neural retinal cells [42]. In an in vitro rat retina-explant model, untreated MSCs seemed to transdifferentiate into microglia109 in a way reminiscent of earlier work on MSC transplants in other neurological tissue [43]. Some limited improvement was seen with pre-treatment with brain-derived neurotrophic factor (BDNF), nerve growth factor, and basic fibroblast growth factor (bFGF) in terms of morphological differentiation into retinal neurons and expression of NF200, GFAP, PKC-alpha, and recoverin, but these cells did not express rhodopsin [44].

In an ischemic retina rodent model, MSCs injected into the vitreous cavity have been shown to mature (with 
expression of neuron-specific enolase and neurofilament) and secrete ciliary neurotrophic factor (CNTF), bFGF, and BDNF for at least 4 weeks [45]. Animal studies have also demonstrated that subretinal transplantation of MSCs delays retinal degeneration and preserves retinal function through a trophic response [46]. UCB-derived MSCs have also been shown to be neuroprotective of rat ganglion cells [47]. Very recently, the intravenous administration of BM-derived MSCs was shown to prevent photoreceptor loss and preserve visual function in the Royal College of Surgeons (RCS) rat model of RP [48].

A role for genetically modified MSCs may emerge in the treatment of subretinal neovascularization. It has been shown that BM-derived MSCs accumulate around subretinal membranes induced by retinal laser burns. Intravenous injection of mouse BM-derived MSCs genetically engineered to secrete pigment epithelium-derived factor resulted in smaller neovascular complexes [49].

\section{Induced pluripotent stem cells}

Current methods of producing SCs from adult somatic cells offer an alternative cell source for transplantation. Induced pluripotent stem cells (iPSCs) are morphologically identical to embryonic SCs, display similar gene expression profiles and epigenetic status, and have the potential to form any cell in the body $[45,50]$. These cells have been employed to generate cells for the treatment of various diseases, including diabetes, cardiovascular disease, sickle cell anemia, Parkinson disease, and hemophilia [51-55]. Meyer and colleagues [56] recently showed that iPSCs can differentiate into retinal cell types, whereas a paper by Buchholz and colleagues [57] showed that human iPSCs can be differentiated into retinal pigment epithelial cells that display functionality in vitro.

Carr and colleagues [58] demonstrated that iPSCs can be differentiated into functional iPSC RPE cells and that transplantation of these cells can facilitate the short-term maintenance of photoreceptors through phagocytosis of photoreceptor outer segments. Long-term visual function is maintained in this model of retinal disease even though the xenografted cells are eventually lost, suggesting a secondary protective host cellular response. Zhao and colleagues [59] showed that abnormal gene expression in some cells differentiated from iPSCs can induce $\mathrm{T}$ cell-dependent immune response in syngeneic recipients. Therefore, the immunogenicity of therapeutically valuable cells derived from patient-specific iPSCs should be evaluated before any clinical application of these autologous cells into the patients.

Owing to viral insertions of pluripotency genes, this particular line of iPSC RPE cells cannot be used as a direct therapy, but recent advances in iPSC cell reprogramming technology, including the use of small molecules [60], piggyBac transposition [61,62], nonintegrating episomal vectors [63], and manipulation of endogenous transcription factors [64], should eliminate the risks associated with the integration of SC genes into the genome. Furthermore, the finding that blood cells can be used to derive iPSCs [65] may remove the need for the invasive biopsies required to collect somatic cells and accelerate the ethical production of SC-derived tissue for therapeutic use.

\section{Human embryonic stem cells}

The human embryonic stem cell (hESC) is defined as a cell that can both renew itself by repeated division and differentiate into any one of the 200 or more adult cell types in the human body. An hESC arises from the eightcell stage morula. Outside of normal development, hESCs have been differentiated in vitro into neural cell types and even pigmented epithelium, although controlling their differentiation has proven challenging. Several hESC lines exist and are supported by public research funds. The use of hESCs has significant limitations, including ethical issues, and a risk of teratoma formation, but the chief problem is that we are still struggling to understand the developmental cues that differentiate $\mathrm{hESCs}$ into the specific adult cell types required to repair damaged tissues [66].

Nistor and colleagues [67] showed, for the first time, that three-dimensional early retinal progenitor tissue constructs can be derived from hESCs. Three-dimensional tissue constructs were developed by culturing hESCderived neural retinal progenitors in a matrix on top of hESC-derived RPE cells in a cell culture insert. An osmolarity gradient maintained the nutrition of the three-dimensional cell constructs. Cross-sections through hESC-derived tissue constructs were characterized by immunohistochemistry for various transcription factors and cell markers. Tissue constructs derived from hESCs expressed transcription factors characteristic of retinal development, such as pax6, Otx2, Chx10, retinal RAX, Brn3b (necessary for differentiation of RGCs), and crx and $\mathrm{nrl}$ (which have a role in photoreceptor development). Many cells expressed neuronal markers, including nestin, beta-tubulin, and microtubule-associated protein.

Assessments of safety and efficacy are crucial before hESC therapies can move into the clinic. Two important early potential hESC applications are the use of RPE cells for the treatment of AMD and Stargardt disease, an untreatable form of macular dystrophy that leads to early-onset blindness. Long-term safety and function of RPE from hESCs in preclinical models of macular degeneration were demonstrated by $\mathrm{Lu}$ and colleagues [68]. They showed long-term functional rescue by using hESC-derived RPE in both RCS rats and Elov14 mice, which are animal models of retinal degeneration and 
Table 1. Mechanisms of the paracrine effect

\begin{tabular}{|c|c|}
\hline Paracrine effect & Mechanisms \\
\hline Increased angiogenesis & $\begin{array}{l}\text { Stem cells produce local signaling molecules that may improve perfusion and enhance angiogenesis to chronically } \\
\text { ischemic tissue. Although the particular growth factors contributing to this neovascular effect remain to be defined, the } \\
\text { list includes vascular endothelial growth factor, hepatocyte growth factor, and basic fibroblast growth factor } 2 \text { [84,85]. }\end{array}$ \\
\hline Decreased inflammation & $\begin{array}{l}\text { Stem cells appear to attenuate infarct size and injury by modulating local inflammation. When transplanted into injured } \\
\text { tissue, the stem cell faces a hostile, nutrient-deficient, inflammatory environment and may release substances that limit } \\
\text { local inflammation in order to enhance its survival. Recent studies implicate the release of the anti-inflammatory cytokine } \\
\text { interleukin-10 as playing an integral role in modulating the activity of innate and adaptive immune cells, such as dendritic } \\
\text { cells, T cells, and B cells }[3,83,86] \text {. }\end{array}$ \\
\hline $\begin{array}{l}\text { Anti-apoptotic and } \\
\text { chemotactic signaling }\end{array}$ & $\begin{array}{l}\text { Stem cells in a third pathway promote salvage of tenuous or malfunctioning cell types at the infarct border zone. Injection } \\
\text { of mesenchymal stem cells (MSCs) into a cryo-induced infarct reduces myocardial scar width } 10 \text { weeks } \\
\text { later. MSCs appear to activate an anti-apoptosis signaling system at the infarct border zone and this effectively protects } \\
\text { ischemia-threatened cell types from apoptosis }[3,39,83] \text {. }\end{array}$ \\
\hline $\begin{array}{l}\text { Beneficial remodeling of the } \\
\text { extracellular matrix }\end{array}$ & $\begin{array}{l}\text { Stem cell transplantation alters the extracellular matrix, resulting in a more favorable post-infarct remodeling, } \\
\text { strengthening of the infarct scar, and prevention of deterioration in organ function }[3,83,87] \text {. }\end{array}$ \\
\hline
\end{tabular}

Stargardt disease, respectively. Good manufacturing practice-compliant hESC RPE cells survived subretinal transplantation in RCS rats for prolonged periods (>220 days). The cells sustained visual function and photoreceptor integrity in a dose-dependent fashion without teratoma formation or untoward pathological reactions.

Near-normal functional measurements were recorded at survival of greater than 60 days in RCS rats. To further address safety concerns, a good laboratory practicecompliant study was carried out in the NIH III immunedeficient mouse model. Long-term data (spanning the life of the animals) showed no gross or microscopic evidence of teratoma/tumor formation after subretinal hESC RPE cell transplantation. These results suggest that hESCs could serve as a potentially safe and inexhaustible source of RPE cells for the efficacious treatment of a range of retinal degenerative diseases.

In 2010, the US Food and Drug Administration granted orphan drug designation to RPE cells for Advanced Cell Technology, Inc. (Santa Monica, CA, USA) to initiate its phase $1 / 2$ clinical trials using RPE cells derived from hESCs to treat patients with Stargardt macular dystrophy. Moreover, in 2011, the company received a positive opinion from the Committee for Orphan Medicinal Products of the European Medicines Agency for the designation of this product as an orphan medicinal product for the treatment of Stargardt disease $[69,70]$.

\section{Retinal progenitor cells}

RPCs, considered the active cellular component of fetal retinal transplants, were purified from green fluorescent protein transgenic mice and transplanted into the degenerating retina of a mature mouse model. The transplanted RPCs developed into neurons, including presumptive photoreceptor cells expressing rhodopsin,

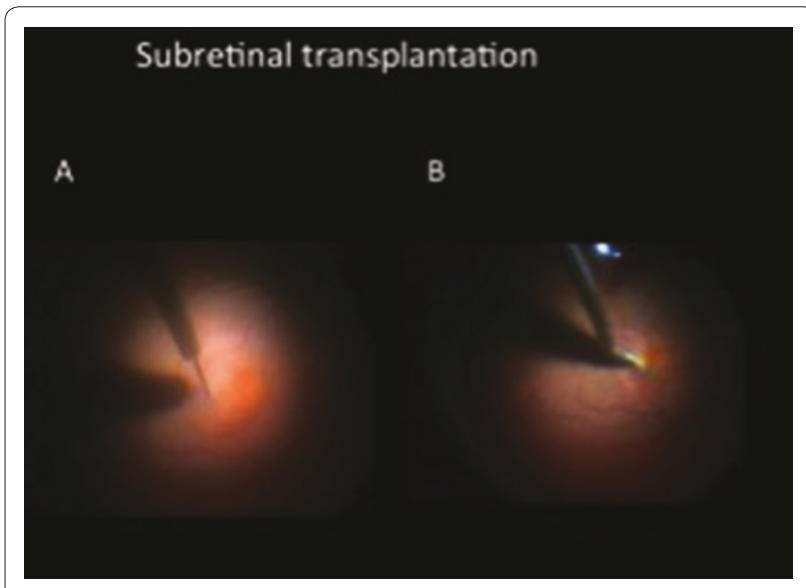

Figure 2. Subretinal technique. In this technique, a cannula is connected to a 1-mL tuberculin syringe (with a screw plunger) containing balanced salt solution (BSS). The BSS is injected slowly to create a retinotomy, and a small subretinal bleb is raised $(\mathbf{A})$. This procedure minimizes retinal trauma. The cannula is introduced through the retinotomy, and the BSS injection restarts and continues to expand the bleb to the correct volume. A process of gentle retinal massage is used to release the tension in the bleb. The cannula is removed, and a 30-gauge cannula, connected to sterile tubing and syringe preloaded with cells, is introduced in the subretinal space (B).

opsin, and recoverin. The host showed rescue of the outer retina layer cells with integration of donor cells occurring in multiple retinal layers. The greatest concentration of integration in the outer retina and, most importantly, recipient mice, demonstrated an improved response to light $[71,72]$.

In adults, the neural retina and RPE have overlapping regenerative capacity after injury (for example, in amphibians, injury can activate both retinal and RPE progenitor cells to mediate regeneration and repair). 
Table 2. Clinical and experimental studies using cell therapy for retinal diseases

\begin{tabular}{|c|c|c|c|c|}
\hline Study & Type of study & Type of injury or illness & Route used & Type and source of cells \\
\hline Otani, et al. [16] & Experimental study in animals & $\begin{array}{l}\text { Mice with retinal } \\
\text { degenerative disease }\end{array}$ & Intravitreous transplantation & $\begin{array}{l}\text { Adult bone marrow- } \\
\text { derived lineage-negative } \\
\text { hematopoietic stem cells }\end{array}$ \\
\hline Wang, et al. [48] & Experimental study in animals & Retinitis pigmentosa & Tail vein & $\begin{array}{l}\text { Pluripotent bone marrow- } \\
\text { derived mesenchymal stem } \\
\text { cells }\end{array}$ \\
\hline Li, et al. [93] & Experimental study in animals & $\begin{array}{l}\text { Rat injured by ischemia/ } \\
\text { reperfusion }\end{array}$ & Intravitreous transplantation & $\begin{array}{l}\text { Bone marrow mesenchymal } \\
\text { stem cells }\end{array}$ \\
\hline Uteza, et al. [94] & Experimental study in animals & $\begin{array}{l}\text { Photoreceptor cell } \\
\text { degeneration in Royal } \\
\text { College of Surgeon rats }\end{array}$ & Intravitreous transplantation & Encapsulated fibroblasts \\
\hline Zhang and Wang [95] & Experimental study in animals & $\begin{array}{l}\text { Light-damaged retinal } \\
\text { structure }\end{array}$ & Subretinal space & $\begin{array}{l}\text { Bone marrow mesenchymal } \\
\text { stem cells }\end{array}$ \\
\hline Tomita, et al. [96] & Experimental study in animals & $\begin{array}{l}\text { Retinas mechanically injured } \\
\text { using a hooked needle }\end{array}$ & Intravitreous transplantation & $\begin{array}{l}\text { Bone marrow-derived stem } \\
\text { cells }\end{array}$ \\
\hline Meyer, et al. [97] & Experimental study in animals & Retinal degeneration & Intravitreous transplantation & Embryonic stem cells \\
\hline Siqueira, et al. [21] & Experimental study in animals & $\begin{array}{l}\text { Chorioretinal injuries caused } \\
\text { by laser red diode } 670 \mathrm{~N}-\mathrm{M}\end{array}$ & Intravitreous transplantation & $\begin{array}{l}\text { Bone marrow-derived stem } \\
\text { cells }\end{array}$ \\
\hline Wang, et al. [98] & Experimental study in animals & $\begin{array}{l}\text { Mice with laser-induced } \\
\text { retinal injury }\end{array}$ & Intravitreous transplantation & $\begin{array}{l}\text { Bone marrow-derived stem } \\
\text { cells }\end{array}$ \\
\hline Johnson, et al. [99] & Experimental study in animals & Glaucoma & Intravitreous transplantation & $\begin{array}{l}\text { Bone marrow-derived } \\
\text { mesenchymal stem cell }\end{array}$ \\
\hline Castanheira, et al. [37] & Experimental study in animals & $\begin{array}{l}\text { Rat retinas submitted to laser } \\
\text { damage }\end{array}$ & Intravitreous transplantation & $\begin{array}{l}\text { Bone marrow-derived } \\
\text { mesenchymal stem cell }\end{array}$ \\
\hline Jonas, et al. [32] & Case report & $\begin{array}{l}\text { Patient with atrophy of the } \\
\text { retina and optic nerve }\end{array}$ & Intravitreous transplantation & $\begin{array}{l}\text { Bone marrow-derived } \\
\text { mononuclear cell } \\
\text { transplantation }\end{array}$ \\
\hline Jonas, et al. [33] & Case report & $\begin{array}{l}\text { Three patients with diabetic } \\
\text { retinopathy, age-related } \\
\text { macular degeneration, } \\
\text { and optic nerve atrophy } \\
\text { (glaucoma) }\end{array}$ & Intravitreous transplantation & $\begin{array}{l}\text { Bone marrow-derived } \\
\text { mononuclear cell } \\
\text { transplantation }\end{array}$ \\
\hline $\begin{array}{l}\text { Siqueira, et al. [34] } \\
\text { ClinicalTrials.gov identifier } \\
\text { NCT01068561 [19] }\end{array}$ & $\begin{array}{l}\text { Clinical trial } \\
\text { Phase I }\end{array}$ & $\begin{array}{l}\text { Five patients with retinitis } \\
\text { pigmentosa }\end{array}$ & Intravitreous transplantation & $\begin{array}{l}\text { Bone marrow-derived } \\
\text { mononuclear cell } \\
\text { transplantation }\end{array}$ \\
\hline $\begin{array}{l}\text { Siqueira [92] } \\
\text { Ethics committee of Brazil } \\
\text { Register: } 16018\end{array}$ & $\begin{array}{l}\text { Clinical trial } \\
\text { Phase II }\end{array}$ & $\begin{array}{l}\text { Fifty patients with retinitis } \\
\text { pigmentosa }\end{array}$ & Intravitreous transplantation & $\begin{array}{l}\text { Bone marrow-derived } \\
\text { mononuclear cell } \\
\text { transplantation }\end{array}$ \\
\hline $\begin{array}{l}\text { Siqueira [92] } \\
\text { Ethics committee of Brazil } \\
\text { Register: } 15978\end{array}$ & $\begin{array}{l}\text { Clinical trial } \\
\text { Phases } 1 / \|\end{array}$ & $\begin{array}{l}\text { Ten patients with macular } \\
\text { degeneration }\end{array}$ & Intravitreous transplantation & $\begin{array}{l}\text { Bone marrow-derived } \\
\text { mononuclear cell } \\
\text { transplantation }\end{array}$ \\
\hline $\begin{array}{l}\text { Siqueira [92] } \\
\text { Ethics Committee of Brazil } \\
\text { Register: } 16062\end{array}$ & $\begin{array}{l}\text { Clinical trial } \\
\text { Phases I/II }\end{array}$ & $\begin{array}{l}\text { Thirty patients with ischemic } \\
\text { retinopathy }\end{array}$ & Intravitreous transplantation & $\begin{array}{l}\text { Bone marrow-derived } \\
\text { mononuclear cell } \\
\text { transplantation }\end{array}$ \\
\hline $\begin{array}{l}\text { Advanced Cell Technology } \\
\text { Inc. [100] }\end{array}$ & $\begin{array}{l}\text { Clinical trial } \\
\text { Phases } 1 / \|\end{array}$ & $\begin{array}{l}\text { Twelve patients with } \\
\text { Stargardt macular dystrophy }\end{array}$ & Subretinal transplantation & $\begin{array}{l}\text { Retinal pigment epithelial } \\
\text { cells derived from human } \\
\text { embryonic stem cells }\end{array}$ \\
\hline
\end{tabular}

Limited damage of amphibian retina activates progenitor cells within the neural retina, presumably retina stem cells (RSCs), to mediate regeneration and repair, whereas extensive damage that destroys most of the neural retina results in the activation of a progenitor cell population within the RPE layer, presumably retinal pigment epithelial SCs, to regenerate both neural retina and RPE $[72,73]$. RSCs have been isolated from the edge of the peripheral region of the neurosensory mammalian retina, although questions regarding the true origin of these cells and the ability to self-renew have been raised [74,75].

More recently, RSCs that demonstrate self-renewal and differentiated progeny have been isolated from the posterior neural retina. Of the multiple types of RSCs and RPCs reported, retinal glial Müller cells are the most studied late progenitors that retain competency to produce neuronal lineages, including photoreceptor cells. Müller glial cells actively regenerate damaged retina in lower animals and can be similarly activated in mice by 
application of growth factors. Although the Müller cells reside in the retina and have properties of RSCs, they also produce all major neural lineages, in which there are multipotent neural SCs [72,76-79].

\section{Endothelial progenitor cells}

Endothelial progenitor cells (EPCs) are a minor population of mononuclear cells circulating in peripheral blood. Though rare in comparison with other blood cells, EPCs are capable of facilitating vascular repair in different ischemic tissues; therefore, EPCs have been regarded as promising candidates for inducing therapeutic angiogenesis in multiple diseases such as acute myocardial infarction, unstable angina, stroke, diabetic microvasculopathies, pulmonary arterial hypertension, atherosclerosis, and ischemic retinopathies [80,81].

Numerous studies suggest that EPCs re-vascularize ischemic tissues, and recent clinical trials have highlighted the feasibility, safety, and potential therapeutic benefit of an EPC-based cytotherapy for myocardial infarction. However, there are still discrepancies about the extent to which these cells incorporate into the vasculature and the level to which they restore functionality to damaged tissue. These controversies are caused by an imprecise EPC definition as many different cell populations are collectively referred to as EPCs. Recently, Medina and colleagues [82] described a distinct EPC population named outgrowth endothelial cells (OECs). OECs were isolated from adult human peripheral blood and grown on collagen substrate. OECs were able to closely interact with mature endothelial cells through adherens and tight junctions. OECs demonstrated de novo tubulogenic potential and fully incorporate into a mature vascular network. This is also demonstrated in vivo, where OECs directly incorporate into resident ischemic vasculature and significantly decreased avascular areas $(P<0.001)$ when compared with vehicle-injected retinas. The authors concluded that OECs have great potential as an alternative treatment for ischemic retinopathies [82].

\section{Possible mechanisms of retinal function recovery with the use of cell therapy (paracrine effect)}

SCs may be able to restore the functioning of the retina through two paths: cell replacement (described above with the different types of SC) and rescue therapy (the paracrine effect). The paracrine effect is defined as an action exerted by a substance secreted by a cell on local cellular environments. Some cell-to-cell communication requires direct cell-to-cell contact. Some cells can form gap junctions that connect their cytoplasm to the cytoplasm of adjacent cells. In cardiac muscle, gap junctions between adjacent cells allow action potential propagation from the cardiac pacemaker region of the heart to spread and coordinately cause contraction of the heart.

SCs transplanted into injured tissue express paracrine signaling factors, including cytokines, chemokines, and growth factors, which are involved in orchestrating the SC-driven repair process. However, our understanding of the mechanistic basis for SC-mediated paracrine enhancement of end-organ function remains incomplete. The paracrine effect can be divided into several mechanisms and may benefit the treatment of retinal diseases, helping to improve the functioning of cells, as described in Table $1[3,26,39,83-87]$.

\section{Routes of stem cell transplantation for retinal diseases}

Routes that were tested for cell therapy for retinal diseases are systemic administration (intravenous), intravitreal injection, and subretinal injection (Figure 1). Figure 2 shows the two subretinal injection techniques: (A) injection of cell suspensions and (B) injection of cells adhered to a matrix (scaffold) [20,88-90].

\section{Conclusions}

SCs maintain the balance between somatic cell populations in various tissues and are responsible for organ regeneration. The remarkable progress of regenerative medicine in the last few years indicates promise for the use of SCs in the treatment of ophthalmic disorders. Based on the abovementioned mechanisms, experimental and human studies with intravitreal BM-derived SCs have begun (Table 2) [91,92]. History is starting to be written in this very promising therapeutic field.

\begin{abstract}
Abbreviations
ABMC, autologous bone marrow-derived mononuclear cell; AMD, age-related macular degeneration; BDNF, brain-derived neurotrophic factor; bFGF, basic fibroblast growth factor; $\mathrm{BM}$, bone marrow; $\mathrm{EPC}$, endothelial progenitor cell; hESC, human embryonic stem cell; HSC, hematopoietic stem cell; iPSC, induced pluripotent stem cell; Lin-HSC, lineage-negative hematopoietic stem cell; MSC, mesenchymal stem cell; OEC, outgrowth endothelial cell; RCS, Royal College of Surgeons; RGC, retinal ganglion cell; RP, retinitis pigmentosa; RPC, retinal progenitor cell; RPE, retinal pigment epithelium; RSC, retina stem cell; SC, stem cell; UCB, umbilical cord blood.
\end{abstract}

Competing interests

The author declares that he has no competing interests.

\section{Acknowledgments}

I thank Júlio Cesar Voltarelli, André Marcio Vieira Messias, and Rodrigo Jorge, who are medical researchers at the University of São Paulo (Ribeirão Preto, São Paulo, Brazil) and who are participating in the clinical study of stem cells for treatment of retinitis pigmentosa.

\section{Author details}

'São Paulo University, Ribeirão Preto, Rua Saldanha Marinho 2815 conj 42, São Paulo 15010-100, Brazil. ${ }^{2}$ Rubens Siqueira Research Center, Sao Jose do Rio

Preto, Rua Saldanha Marinho 2815 conj 42, São Paulo 15010-100, Brazil. ${ }^{3}$ Retina Cell, Sao Jose do Rio Preto, Rua Saldanha Marinho 2815 conj 42, São Paulo 15010-100, Brazil.

Published: 29 December 2011 


\section{References}

1. Lorenz E, Congdon C, Uphoff D: Modification of acute irradiation injury in mice and guinea-pigs by bone marrow injections. Radiology 1951, 58:863-877.

2. Till JE, McCulloch EA: A direct measurement of the radiation sensitivity of normal mouse bone marrow cells. Radiat Res 1961, 14:213-222.

3. Siqueira RC, Voltarelli JC, Messias AM, Jorge R: Possible mechanisms of retinal function recovery with the use of cell therapy with bone marrowderived stem cells. Ara Bras Oftalmol 2010, 73:474-479.

4. Lanza R, Rosenthal N: The stem cell challenge. Sci Am 2004, 290:93-99.

5. Mimeault M, Batra SK: Concise review: recent advances on the significance of stem cells in tissue regeneration and cancer therapies. Stem Cells 2006, 24:2319-2345.

6. Ortiz-Gonzalez XR, Keene CD, Verfaillie C, Low WC: Neural induction of adult bone marrow and umbilical cord stem cells. Curr Neurovasc Res 2004, 1:207-213.

7. Trounson A: The production and directed differentiation of human embryonic stem cells. Endocr Rev 2006, 27:208-219. Review.

8. Kolb H: Simple anatomy of the retina. In Webvision: The Organization of the Retina and Visual System [Internet]. Edited by Kolb H, Fernandez E, Nelson R. Salt Lake City, UT: University of Utah Health Sciences Center; 1995 to 1 May 2005 [updated 1 May 2007].

9. Machalinska A, Baumert B, Kuprjanowicz L, Wiszniewska B, Karczewicz D, Machalinski B: Potential application of adult stem cells in retinal repair challenge for regenerative medicine. Curr Eye Res 2009, 34:748-760. Review.

10. Bunce C, Wormald R: Leading causes of certification for blindness and partial sight in England \& Wales. BMC Public Health 2006, 6:58.

11. Chakravarthy U, Evans J, Rosenfeld PJ: Age related macular degeneration. BMJ 2010, 340:c981.

12. Maier PC, Funk J, Schwarzer G, Antes G, Falck-Ytter YT: Treatment of ocular hypertension and open angle glaucoma: meta-analysis of randomised controlled trials. BMJ 2005, 331:134

13. O'Doherty M, Dooley I, Hickey-Dwyer M: Interventions for diabetic macular oedema: a systematic review of the literature. Br J Ophthalmol 2008, 92:1581-1590.

14. Mohamed Q, Gillies MC, Wong TY: Management of diabetic retinopathy: a systematic review. JAMA 2007, 298:902-916.

15. Dahlmann-Noor A, Vijay S, Jayaram H, Limb A, Khaw PT: Current approache and future prospects for stem cell rescue and regeneration of the retina and optic nerve. Can J Ophthalmol 2010,45:333-341.

16. Otani A, Dorrell MI, Kinder K, Moreno SK, Nusinowitz S, Banin E, Heckenlively J, Friedlander M: Rescue of retinal degeneration by intravitreally injected adult bone marrow-derived lineagenegative hematopoietic stem cells. J Clin Invest 2004, 114:765-774. Comment in: J Clin Invest 2004, 114:755-757.

17. Otani A, Kinder K, Ewalt K, Otero FJ, Schimmel P, Friedlander M: Bone marrow-derived stem cells target retinal astrocytes and can promote or inhibit retinal angiogenesis. Nat Med 2002, 8:1004-1010. Comment in: Nat Med 2002, 8:932-934

18. Siqueira RC, Messias A, Voltarelli JC, Scott I, Jorge R: Autologous bone marrow-derived stem cells transplantation for retinitis pigmentosa. Cytotherapy 2010, 12 Suppl 1:58.

19. Autologous Bone Marrow-Derived Stem Cells Transplantation for Retinitis Pigmentosa. ClinicalTrials.gov identifier: NCT01068561 [http://clinicaltrials. gov/ct2/show/NCT01068561].

20. Siqueira RC: Autologous transplantation of retinal pigment epithelium in age related macular degeneration. Ara Bras Oftalmo/ 2009, 72:123-130.

21. Siqueira RC, Abad L, Benson G, Sami M: Behaviour of stem cells in eyes of rabbits with chorioretinal injuries caused by laser red diode $670 \mathrm{~N}-\mathrm{M}$. In: Annual Meeting of the Association for Research in Vision and Ophthalmology (ARVO), 2008, Fort Lauderdale. Invest Ophthalmol Vis Sci 2008, 49:536.

22. Enzmann V, Yolcu E, Kaplan HJ, Ildstad ST: Stem cells as tools in regenerative therapy for retinal degeneration. Arch Ophthalmol 2009, 127:563-571.

23. Müller-Sieburg CE, Cho RH, Thoman M, Adkins B, Sieburg HB: Deterministic regulation of hematopoietic stem cell self-renewal and differentiation. Blood 2002, 100:1302-1309.

24. Ratajczak MZ, Kucia M, Reca R, Majka M, Janowska-Wieczorek A, Ratajczak J: Stem cell plasticity revisited: CXCR4-positive cells expressing mRNA for early muscle, liver and neural cells 'hide out' in the bone marrow. Leukemia 2004, 18:29-40.

25. Spangrude GJ, Heimfeld S, Weissman IL: Purification and characterization of mouse hematopoietic stem cells. Science 1988, 241:58-62. Erratum in:
Science 1989, 244:1030

26. Cheng AS, Yau TM: Paracrine effects of cell transplantation: strategies to augment the efficacy of cell therapies. Semin Thorac Cardiovasc Surg 2008, 20:94-101.

27. Nielsen JS, MCNagny KM: CD34 is a key regulator of hematopoietic stem cell trafficking to bone marrow and mast cell progenitor trafficking in the periphery. Microcirculation 2009, 16:487-496.

28. Kuçi S, Kuçi Z, Latifi-Pupovci H, Niethammer D, Handgretinger R, Schumm M, Bruchelt $G$, Bader P, Klingebiel T: Adult stem cells as an alternative source of multipotential (pluripotential) cells inregenerative medicine. Curr Stem Cell Res Ther 2009, 4:107-117.

29. Challen GA, Boles N, Lin KK, Goodell MA: Mouse hematopoietic stem cell identification and analysis. Cytometry A 2009, 75:14-24. Review.

30. Voltarelli JC, Ouyang J: Hematopoietic stem cell transplantation for autoimmune diseases in developing countries: current status and future perspectives. Bone Marrow Transplant 2003, 32 Suppl 1:S69-71.

31. Voltarelli JC: Applications of flow cytometry to hematopoietic stem cell transplantation. Mem Inst Oswaldo Cruz 2000, 95:403-414.

32. Jonas JB, Witzens-Harig M, Arseniev L, Ho AD: Intravitreal autologous bone marrow-derived mononuclear cell transplantation: a feasibility report. Acta Ophthalmol 2008, 86:225-226

33. Jonas JB, Witzens-Harig M, Arseniev L, Ho AD: Intravitreal autologous bone marrow-derived mononuclear cell transplantation. Acta Ophthalmol 2010, 88:e131-132.

34. Siqueira RC, Messias A, Voltarelli JC, Scott IU, Jorge R: Intravitreal injection of autologous bone marrow-derived mononuclear cells for hereditary retinal dystrophy: a phase I trial. Retina 2011, 31:1207-1214.

35. Horwitz EM, Le Blanc K, Dominici M, Mueller I, Slaper-Cortenbach I, Marini FC, Deans RJ, Krause DS, Keating A; International Society for Cellular Therapy: Clarification of the nomenclature for MSC: The International Society for Cellular Therapy position statement. Cytotherapy 2005, 7:393-395.

36. Phinney DG, Prockop DJ: Concise review: mesenchymal stem/multipotent stromal cells: the state of transdifferentiation and modes of tissue repaircurrent views. Stem Cells 2007, 25:2896-2902

37. Castanheira P, Torquetti L, Nehemy MB, Goes AM: Retinal incorporation and differentiation of mesenchymal stem cells intravitreally injected in the injured retina of rats. Arq Bras Oftalmo/ 2008, 71:644-650.

38. Gong L, Wu Q, Song B, Lu B, Zhang Y: Differentiation of rat mesenchymal stem cells transplanted into the subretinal space of sodium iodateinjected rats. Clin Experiment Ophthalmol 2008, 36:666-671.

39. Zhang P, Li J, Liu Y, Chen X, Kang Q, Zhao J, Li W: Human neural stem cell transplantation attenuates apoptosis and improves neurological functions after cerebral ischemia in rats. Acta Anaesthesio/ Scand 2009, 53:1184-1191.

40. Vossmerbaeumer U, Ohnesorge S, Kuehl S, Haapalahti M, Kluter H, Jonas $\mathrm{JB}$, Thierse HJ, Bieback K: Retinal pigment epithelial phenotype induced in human adipose tissue-derived mesenchymal stromal cells. Cytotherapy 2009, 11:177-188.

41. Arnhold S, Heiduschka P, Klein H, Absenger Y, Basnaoglu S, Kreppel F, HenkeFahle S, Kochanek S, Bartz-Schmidt KU, Addicks K, Schraermeyer U: Adenovirally transduced bone marrow stromal cells differentiate into pigment epithelial cells and induce rescue effects in RCS rats. Invest Ophthalmol Vis Sci 2006, 47:4121-4129.

42. Yu J, Vodyanik MA, Smuga-Otto K, Antosiewicz-Bourget J, Frane JL, Tian S, Nie J, Jonsdottir GA, Ruotti V, Stewart R, Slukvin II, Thomson JA: Induced pluripotent stem cell lines derived from human somatic cells. Science 2007, 318:1917-1920.

43. Azizi SA, Stokes D, Augelli BJ, DiGirolamo C, Prockop DJ: Engraftment and migration of human bone marrow stromal cells implanted in the brains of albino rats-Similarities to astrocyte grafts. Proc Natl Acad Sci U S A 1998, 95:3908-3913.

44. Erices $A$, Conget $P$, Minguell JJ: Mesenchymal progenitor cells in human umbilical cord blood. Br J Haematol 2000, 109:235-242.

45. Li W, Zhou H, Abujarour R, Zhu S, Young Joo J, Lin T, Hao E, Schöler HR, Hayek A, Ding S: Generation of human induced pluripotent stem cells in the absence of exogenous Sox2. Stem Cells 2009, 27:2992-3000.

46. Inoue $Y$, Iriyama A, Ueno $S$, Takahashi $H$, Kondo M, Tamaki Y, Araie M, Yanagi Y: Subretinal transplantation of bone marrow mesenchymal stem cells delays retinal degeneration in the RCS rat model of retinal degeneration. Exp Eye Res 2007, 85:234-241.

47. Zwart I, Hill AJ, Al-Allaf F, Shah M, Girdlestone J, Sanusi AB, Mehmet H, 
Navarrete R, Navarrete C, Jen LS: Umbilical cord blood mesenchymal stromal cells are neuroprotective and promote regeneration in a rat optic tract model. Exp Neurol 2009, 216:439-448.

48. Wang S, Lu B, Girman S, Duan J, McFarland T, Zhang QS, Grompe M, Adamus G, Appukuttan B, Lund R: Non-invasive stem cell therapy in a rat model for retinal degeneration and vascular pathology. PLOS ONE 2010, 5:e9200.

49. Hou HY, Liang HL, Wang YS, Zhang ZX, Wang BR, Shi YY, Dong X, Cai Y: A therapeutic strategy for choroidal neovascularization based on recruitment of mesenchymal stem cells to the sites of lesions. Mol Ther 2010, 18:1837-1845.

50. Takahashi K, Tanabe K, Ohnuki M, Narita M, Ichisaka T, Tomoda K, Yamanaka S: Induction of pluripotent stem cells from adult human fibroblasts by defined factors. Cell 2007, 131:861-872.

51. Zhang D, Jiang W, Liu M, Sui X, Yin X, Chen S, Shi Y, Deng H: Highly efficient differentiation of human ES cells and iPS cells into mature pancreatic insulin-producing cells. Cell Res 2009, 52:615-621.

52. Zhang J, Wilson GF, Soerens AG, Koonce CH, Yu J, Palecek SP, Thomson JA, Kamp TJ: Functional cardiomyocytes derived from human induced pluripotent stem cells. Circ Res 2009, 104:e30-41.

53. Hanna J, Wernig M, Markoulaki S, Sun CW, Meissner A, Cassady JP, Beard C, Brambrink T, Wu LC, Townes TM, Jaenisch R: Treatment of sickle cell anemia mouse model with iPS cells generated from autologous skin. Science 2007, 318:1920-1923.

54. Xu D, Alipio Z, Fink LM, Adcock DM, Yang J, Ward DC, Ma Y: Phenotypic correction of murine hemophilia A using an iPS cell-based therapy. Proc Natl Acad Sci U S A 2009, 106:80.

55. Wernig M, Zhao JP, Pruszak J, Hedlund E, Fu D, Soldner F, Broccoli V, Constantine-Paton M, Isacson O, Jaenisch R: Neurons derived from reprogrammed fibroblasts functionally integrate into the fetal brain and improve symptoms of rats with Parkinson's disease. Proc Natl Acad Sci U S A 2008, 105:5856-5861.

56. Meyer JS, Shearer RL, Capowski EE, Wright LS, Wallace KA, McMillan EL, Zhang SC, Gamm DM: Modeling early retinal development with human embryonic and induced pluripotent stem cells. Proc Natl Acad SciU S A 2009, 106:16698-16703.

57. Buchholz DE, Hikita ST, Rowland TJ, Friedrich AM, Hinman CR, Johnson LV, Clegg DO: Derivation of functional retinal pigmented epithelium from induced pluripotent stem cells. Stem Cells 2009, 27:2427-2434.

58. Carr AJ, Vugler AA, Hikita ST, Lawrence JM, Gias C, Chen LL, Buchholz DE, Ahmado A, Semo M, Smart MJ, Hasan S, da Cruz L, Johnson LV, Clegg DO, Coffey PJ: Protective effects of human iPS-derived retinal pigment epithelium cell transplantation in the retinal dystrophic rat. PLoS One 2009, 4:e8152.

59. Zhao T, Zhang ZN, Rong Z, Xu Y: Immunogenicity of induced pluripotent stem cells. Nature 2011, 474:212-215.

60. Shi Y, Desponts C, Do JT, Hahm HS, Schöler HR, Ding S: Induction of pluripotent stem cells from mouse embryonic fibroblasts by Oct4 and KIf4 with small-molecule compounds. Cell Stem Cell 2008, 3:568-574.

61. Woltjen K, Michael IP, Mohseni P, Desai R, Mileikovsky M, Hämäläinen R, Cowling R, Wang W, Liu P, Gertsenstein M, Kaji K, Sung HK, Nagy A: piggyBac transposition reprograms fibroblasts to induced pluripotent stem cells. Nature 2009, 458:766-770.

62. Kaji K, Norrby K, Paca A, Mileikovsky M, Mohseni P, Woltjen K: Virus-free induction of pluripotency and subsequent excision of reprogramming factors. Nature 2009, 458:771-775.

63. Yu J, Hu K, Smuga-Otto K, Tian S, Stewart R, Slukvin II, Thomson JA: Human induced pluripotent stem cells free of vector and transgene sequences. Science 2009, 324:797-801

64. Balasubramanian S, Babai N, Chaudhuri A, Qiu F, Bhattacharya S, Dave BJ, Parameswaran S, Carson SD, Thoreson WB, Sharp JG, Rao M, Ahmad I: Non cell-autonomous reprogramming of adult ocular progenitors: generation of pluripotent stem cells without exogenous transcription factors. Stem Cells 2009, 27:3053-3062.

65. Loh YH, Agarwal S, Park IH, Urbach A, Huo H, Heffner GC, Kim K, Miller JD, Ng K, Daley GQ: Generation of induced pluripotent stem cells from human blood. Blood 2009, 113:5476-5479.

66. MacLaren RE, Pearson RA: Stem cell therapy and the retina. Eye 2007 21:1352-1359.

67. Nistor G, Seiler MJ, Yan F, Ferguson D, Keirstead HS: Three-dimensional early retinal progenitor $3 \mathrm{D}$ tissue constructs derived from human embryonic stem cells. J Neurosci Methods 2010, 190:63-70.
68. Lu B, Malcuit C, Wang S, Girman S, Francis P, Lemieux L, Lanza R, Lund R: Long-term safety and function of RPE from human embryonic stem cells in preclinical models of macular degeneration. Stem Cells 2009, 27:2126-2135.

69. Idelson M, Alper R, Obolensky A, Ben-Shushan E, Hemo I, Yachimovich-Cohen N, Khaner H, Smith Y, Wiser O, Gropp M, Cohen MA, Even-Ram S, BermanZaken Y, Matzrafi L, Rechavi G, Banin E, Reubinoff B: Directed differentiation of human embryonic stem cells into functional retinal pigment epithelium cells. Cell Stem Cell 2009, 5:396-408.

70. Vugler A, Lawrence J, Walsh J, Carr A, Gias C, Semo M, Ahmado A, da Cruz L, Andrews P, Coffey P: Embryonic stem cells and retinal repair. Mech Dev 2007, 124:807-829

71. Klassen HJ, Ng TF, Kurimoto Y, Kirov I, Shatos M, Coffey P, Young MJ: Multipotent retinal progenitors express developmental markers, differentiate into retinal neurons, and preserve light-mediated behavior. Invest Ophthalmol Vis Sci 2004, 45:4167-4173.

72. Stern JH, Temple S: Stem cells for retinal replacement therapy. Neurotherapeutics 2011, 8:736-743.

73. Stone LS: Neural retina degeneration followed by regeneration from surviving retinal pigment cells in grafted adult salamander eyes. Anat Rec 1950, 106:89-109.

74. Tropepe V, Coles BL, Chiasson BJ, Horsford DJ, Elia AJ, McInnes RR, van der Kooy D: Retinal stem cells in the adult mammalian eye. Science 2000 287:2032-2036.

75. Ahmad I, Tang L, Pham H: Identification of neural progenitors in the adult mammalian eye. Biochem Biophys Res Commun 2000, 270:517-521.

76. Cicero SA, Johnson D, Reyntiens S, Frase S, Connell S, Chow LM, Baker SJ, Sorrentino BP, Dyer MA: Cells previously identified as retinal stem cells are pigmented ciliary epithelial cells. Proc Natl Acad Sci U S A 2009, 106:6685-6690.

77. Moshiri A, Reh TA: Persistent progenitors at the retinal margin of ptc+/mice. J Neurosci 2004, 24:229-237.

78. Karl MO, Hayes S, Nelson BR, Tan K, Buckingham B, Reh TA: Stimulation of neural regeneration in the mouse retina. Proc Natl Acad SciU S A 2008, 105:19508-19513.

79. Das AV, Mallya KB, Zhao X, Ahmad F, Bhattacharya S, Thoreson WB, Hegde GV Ahmad I: Neural stem cell properties of Muller glia in the mammalian retina: regulation by Notch and Wnt signaling. Dev Bio/ 2006, 299:283-302.

80. Rafii S, Lyden D: Therapeutic stem and progenitor cell transplantation for organ vascularization and regeneration. Nat Med 2003, 9:702-712.

81. Medina RJ, O'Neill CL, Sweeney M, Guduric-Fuchs J, Gardiner TA, Simpson DA Stitt AW: Molecular analysis of endothelial progenitor cell (EPC) subtypes reveals two distinct cell populations with different identities. BMC Med Genomics 2010, 3:18

82. Medina RJ, O'Neill CL, O'Doherty TM, Guduric-Fuchs J, Gardiner TA, Stitt AW: Endothelial progenitor cells contribute to vascular repair in the ischaemic retina. Heart 2011, 97:e7.

83. Crisostomo PR, Markel TA, Wang Y, Meldrum DR: Surgically relevant aspects of stem cell paracrine effects. Surgery 2008, 143:577-581.

84. Markel TA, Wang Y, Herrmann JL, Crisostomo PR, Wang M, Novotny NM, Herring CM, Tan J, Lahm T, Meldrum DR: VEGF is critical for stem cellmediated cardioprotection and a crucial paracrine factor for defining the age threshold in adult and neonatal stem cell function. Am J Physiol Heart Circ Physiol 2008, 295:H2308-2314.

85. Markel TA, Crisostomo PR, Wang M, Herring CM, Meldrum DR: Activation of individual tumor necrosis factor receptors differentially affects stem cell growth factor and cytokine production. Am J Physiol Gastrointest Liver Physiol 2007, 293:G657-662

86. Oh JY, Kim MK, Shin MS, Lee HJ, Ko JH, Wee WR, Lee JH: The antiinflammatory and anti-angiogenic role of mesenchymal stem cells in corneal wound healing following chemical injury. Stem Cells 2008 26:1047-1055.

87. Koontongkaew S, Amornphimoltham P, Yapong B: Tumor-stroma interactions influence cytokine expression and matrix metalloproteinase activities in paired primary and metastatic head and neck cancer cells. Cell Biol Int 2009, 33:165-173.

88. Binder S, Stanzel BV, Krebs I, Glittenberg C: Transplantation of the RPE in AMD. Prog Retin Eye Res 2007, 26:516-515.

89. Falkner-Radler CI, Krebs I, Glittenberg C, Povazay B, Drexler W, Graf A, Binder S: Human retinal pigment epithelium (RPE) transplantation: outcome after autologous RPE-choroid sheet and RPE cell-suspension in a randomised 
clinical study. Br J Ophthalmol 2011, 95:370-375.

90. Singh MS, Maclaren RE: Stem cells as a therapeutic tool for the blind: biology and future prospects. Proc Biol Sci 2011, 278:3009-3016.

91. Ballios BG, van der Kooy D: Biology and therapeutic potential of adult retinal stem cells. Can J Ophthalmol 2010, 45:342-351.

92. Siqueira RC: Stem-cell therapy for retinal diseases. In Embryonic Stem Cells - Differentiation and Pluripotent Alternatives. Edited by Kallos MS. Rijeka, Croatia: InTech; 2011 [http://www.intechopen.com/articles/show/title/ stem-cell-therapy-for-retinal-diseases].

93. Li N, Li XR, Yuan JQ: Effects of bone-marrow mesenchymal stem cells transplanted into vitreous cavity of rat injured by ischemia/reperfusion. Graefes Arch Clin Exp Ophthalmol 2009, 247:503-514.

94. Uteza Y, Rouillot JS, Kobetz A, Marchant D, Pecqueur S, Arnaud E, Prats H, Honiger J, Dufier JL, Abitbol M, Neuner-Jehle M: Intravitreous transplantation of encapsulated fibroblasts secreting the human fibroblast growth factor 2 delays photoreceptor cell degeneration in Royal College of Surgeons rats. Proc Natl Acad Sci U S A 1999, 96:3126-3131.

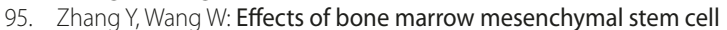
transplantation on light-damaged retina. Invest Ophthalmol Vis Sci 2010, 51:3742-3748

96. Tomita M, Adachi Y, Yamada H, Takahashi K, Kiuchi K, Oyaizu H, Ikebukuro K,
Kaneda $\mathrm{H}$, Matsumura M, Ikehara S: Bone marrow-derived stem cells can differentiate into retinal cells in injured rat retina. Stem Cells 2002, 20:279-283.

97. Meyer JS, Katz ML, Maruniak JA, Kirk MD: Embryonic stem cell-derived neural progenitors incorporate into degenerating retina and enhance survival of host photoreceptors. Stem Cells 2006, 24:274-283.

98. Wang HC, Brown J, Alayon H, Stuck BE: Transplantation of quantum dotlabelled bone marrow-derived stem cells into the vitreous of mice with laser-induced retinal injury: survival, integration and differentiation. Vision Res 2010, 50:665-673.

99. Johnson TV, Bull ND, Hunt DP, Marina N, Tomarev SI, Martin KR: Neuroprotective effects of intravitreal mesenchymal stem cell transplantation in experimental glaucoma. Invest Ophthalmol Vis Sci 2010, 51:2051-2059.

100. Advanced Cell Technology, Inc. homepage [http://www.advancedcell.com].

doi:10.1186/scrt91

Cite this article as: Siqueira RC: Stem cell therapy for retinal diseases: update. Stem Cell Research \& Therapy 2011, 2:50. 